$\xi=-1$

\title{
Exploration of Spiritual Elements in Holistic-Entrepreneur (Holistic-E): Student Development Perspectives
}

\author{
Mohamad, N. H. ${ }^{1}$, Selamat, A. ${ }^{2}$ \\ ${ }^{1}$ Faculty of Technical \& Vocational Education, University Tun Hussein Onn Malaysia, Johore Malaysia \\ ${ }^{2}$ Faculty of Technical \& Vocational Education, University Tun Hussein Onn Malaysia, Johore Malaysia \\ *Corresponding author E-mail: haeranimohamad@gmail.com
}

\begin{abstract}
The Entrepreneurship is seen as a potential career path for overcoming the problem of unemployment. However, this career has yet to get a second or even a last option among graduates in Malaysia. Government has introduced several initiatives to cultivate entrepreneurial spirit among students or graduates such as the first surge of the Malaysia Education Blueprint 2015-2025 (Higher Education) and Entrepreneurship Action Plan 2016-2020. Despite the magnitude of these efforts, little is known whether graduates today are entrepreneurial. Furthermore, based on current achievements, this is quite difficult to implement as the desire of graduates in entrepreneurship is not particularly encouraging, especially graduates in technical courses. Compared to previous studies on student development that only examines the external element of the student affecting entrepreneurial desires, this study focuses on the internal elements of students holistically to increase student entrepreneurial desires and improve entrepreneurship as one of the preferred careers in Malaysia in meeting the challenges of the first shift of the Malaysia Education Blueprint 2015-2025; produce more graduate entrepreneurs.
\end{abstract}

Keywords: Spiritual elements; student's entrepreneur desires; graduate entrepreneur

\section{Introduction}

\subsection{Entrepreneurship Not As Graduated Career Choice}

Career in entrepreneurship is growing and contributing to the country's economic growth. This field has become a career choice for the younger generation, especially in developed countries as well as being seen as an alternative career in overcoming unemployment issues especially among graduates (1). The field of entrepreneurship provides a great opportunity to venture into a career. However, the situation is far different from the situation in Malaysia as this career is still less favorable to the graduates and youth in Malaysia. This is clearly evident through the reference (2) found that only 50.37 percent of Malaysians regard entrepreneurship as a career option. The Global Statistics Entrepreneurship Monitor (GEM) report in 2016 also found that Malaysia is still among the countries with the lowest score in choosing entrepreneurship as an optional career which is 44.10 percent compared to the countries with the highest and medium scores Indonesia (69\%), China (70.3\%) and Thailand $(77.7 \%)$. These statistical data clearly demonstrate the diminution of the interest and the desire of Malaysians in the field of entrepreneurship as a career choice.

Regarding the failure of graduates to allocate themselves in the employment sector, job-dependent attitudes and less interest in entrepreneurial fields actually plunge people into uncertain situations (3). This has actually created pressure on the job market, especially the government that has struggled to ensure that the people have jobs. Reference (4) argue that most individuals, especially graduates are more dependent on others to give them a job than to 'create' their own jobs by making entrepreneurship a career of their choice. In fact, if someone is involved with entrepreneur- ship, they can not only create jobs for themselves but also give jobs to others who work with them in addition to eradicating the wage and unemployment culture among Malaysians.

Hence, in 2015, the government has launched the Malaysia Education Blueprint 20152025 (Higher Education) (5) which is set in line with the aspirations of the Ministry of Education to create the best educational system to enable the country to compete in the world economy. To ensure the effectiveness of its implementation, major changes also involve the role of the ministry, among others, to set up a higher education system capable of producing graduate entrepreneur, not just wage earner. To encourage in venture into entrepreneurship, the Entrepreneurial Action Plan (Higher Education Institution) 2016-2020 is also being implemented to fulfill the aspirations and aspirations of the country in producing graduate entrepreneur.

\subsection{Spirituality in Entrepreneurship}

The world, in the twenty first century, is unprecedentedly embracing entrepreneurship development as a more sustainable way of harnessing the potentials of the enterprising/spiritual man thus ensuring employment generation and economic development. This came to be against the backdrop of the shrinking ability of governments and big organizations to create and provide job opportunities for the ever increasing job seekers. Spirituality is an inner experience by an individual who, through connection with others and a higher power, finds meaning and purpose in life (6). Similarly, reference (7) defined spirituality as a state of being and experience that comes through transcendental awareness which is reflected by particular identifiable values with respect to self, others, nature, life and whatever somebody considers to be the ultimate. Reference (8) agreed that spirituality is an experience but further noted that it is that inner feeling of love and social justice 
that enables someone to transform one's vision and feelings beyond the ordinary and to discern extraordinarily, godly (Godly) presence in one's life and the universe. Spirituality in entrepreneurship as an emerging area of interest has begun to generate attention from management scholars. However, most research in this area is from the western perspective. Until recently, there is dearth of research that gears towards spirituality in Islam and its contribution to the overall development of modern organizations (9). It has been suggested that spirituality in Islam has the potential to positively influence the entrepreneurial outcomes considered (10).

\section{Literature Review}

\subsection{Efforts and Challenges in Holistic Student Devel- opment for Producing Graduate Entrepreneurship Through the First Shift of Malaysia Education Blue- print 2015 - 2025 (Higher Education): Holistic, Entre- preneurial and Balanced Graduates}

There is a mismatch in the supply and demand of graduates, with employers reporting that graduates lack the requisite knowledge, skills and attitudes. This mismatch is only expected to get tougher to resolve as technological disruptions reshape industries and alter the types of jobs available. Preparing Malaysian youth to navigate this uncertain future not only requires imbuing them with transferrable skills and sound ethical foundations, but also the resilience and enterprising spirit to forge new opportunities for themselves and others. It is important to move from a world of job seekers to a world of job creators. Structured and holistic entrepreneurial programs at higher education institutions of Malaysia (HEIs) provided opportunities for students to generate income while studying and also enhancing their level of employability. In line with the first shift of Malaysia Education Blueprint 2015 - 2025 (Higher Education), the Ministry of Higher Education (MOHE) has developed the Higher Education Entrepreneurial Action Plan 20162020 to foster entrepreneurial minds into the entire higher education system in order to produce a holistic, entrepreneurial and balanced career as a job creator. Besides, this efforts also to ensure sustainability financial institutions by acting more entrepreneurial towards higher education funding sources to reduce dependency on government resources (Higher Education Institution Entrepreneur Action Plan 2016-2020).

The Ministry of Higher Education (MOHE) has also introduced Entrepreneurship Development Policy of Higher Education Institutions on 13 April 2010 aims to promote and strengthen entrepreneurship development and education in Higher Education Institutions (HEIs) in a more organized and holistic way. Entrepreneurship Development Policy of Higher Education Institutions consists of; (i) Producing quality human beings and having entrepreneurial thoughts, attributes and values; (ii) Increase the number of graduates of Higher Education Institutions who enter into entrepreneurship as a career; and (iii) Develop academic, researcher and administrators of entrepreneurial Institutions of Higher Learning with an entrepreneurial mind.

Entrepreneurship education is a learning process that aims to create attitudes, values, spirit and mind and entrepreneurial skills in individuals and communities (11). In this regard, the application of entrepreneurial elements should be taken seriously in the planning, management and implementation of the curriculum for mainstream courses at HEIs (12). Despite the increase in entrepreneurship activities and programs in HEIs, these activities and programs are still being implemented beyond the student curriculum This makes it difficult for students to balance time between academic needs and entrepreneurial activities (13). The absence of a guideline for applying entrepreneurial elements and values across the curriculum also makes this aspect difficult to implement more effectively and effectively in most local HEIs (14). Efforts to inculcate entrepreneurial values and elements in teaching and learn- ing need neat restructuring and new cultural work transformation as every higher educational institution, university, polytechnic and community college has its own vision, mission and objectives, as well as having differences in such aspects as culture, norms and traditions in teaching and emphasis on research and certain areas of study.

Additionally, the participation and involvement of academics, researchers and administrators also contributes to the incentives of students to participate in entrepreneurship programs at HEIs. Nurturing values and entrepreneurial attributes among students requires the involvement and support of the concerned HEIs community. While the involvement and participation of students in entrepreneurial activities and programs have been significantly enhanced, participation among academics, researchers and administrators of HEIs are still at a low level (15). Various factors have been identified as a possibility that contributes to this imbalance. Among them is the contribution to entrepreneurial activities and programs not to merit or be considered as contributing to the promotion of the HEIs community either academic or administrative. Therefore, HEIs community must be incorporated into the mind and entrepreneurial culture as HEIs community will be more viable and competitive not just locally but internationally. Entrepreneurial culture is also able to ensure HEIs's research and research materials will not end with outputs or products that cannot be commercialized or utilized by the community.

Although there is a consistent increase in the number of HEIs graduates who venture into entrepreneurship as soon as they graduate, the percentage is still very low, which is about $2 \%$ of the number of graduates each year. This data is consistent with the 2014 Global Entrepreneurship Monitor reports that only 50.37\% of Malaysians see entrepreneurship as a good career choice. This phenomenon may limit the tendency of young people to venture into entrepreneurship as a career, especially when it comes to opposition from parents and families. In addition, Malaysia's achievement is also low in terms of aspiration to become entrepreneurial intention. This statement is in line with the results of the study conducted by (16) which shows that the percentage of students' desires and intentions towards entrepreneurship career is low. Based on studies conducted by (17), the unemployment problem among technical graduates is due to lack of interest in selfemployment and entrepreneurship as a major career or alternative career.

\subsection{Entrepreneurship Not as Graduated Career Choice}

In the student development perspectives, apart from the physical and emotional elements, the spiritual element is one of the cores in a holistic student development. This element is the main motivation injection that can propel students or outstanding individuals whether in academia, business or other (18-20). Spiritual elements have gained a place and are popular in western studies such as linking spirituality to workplace $(21,22)$, entrepreneurship (23), leadership (24) and religious (25). These studies shows that the position and the role of spirituality in the western perspective in enhancing management and humanitarian aspects such as job satisfaction, creativity, productivity and motivation. In the context of Islam, the spirituality is the recognition of the tawhid of Allah SWT for a person to move and live according to his will and direction $(26,27)$.

The concept of spirituality is closely related to Islam as all aspects of a Muslim's life depend on it since the purpose of human creation is to worship Allah SWT (28). Hence in Islam there is no separation between worldly and spiritual aspects because the belief and obedience towards Allah SWT takes place in all corners of life. The philosophy of Islamic entrepreneurship is based on the economic philosophy itself in which the business is based on Rabbani or characterized by God (29) as well as establishing the relationship or influence of spiritual elements in entrepreneurial activities. 
Based on previous studies, the researcher found that the spiritual dimension of entrepreneurship including trust, patience, worship, repentance (30-32) trust in Allah (tawakkul), contentment (qana'ah), sincere, patience, dhikr, (33). Meanwhile reference (34) found that there was significant relationship between Islamic taqwa and leadership with the success or achievement of Muslim entrepreneurs in entrepreneurship. In addition reference (35) through his book "Islam: Rujukan Efektif Akhlak Mulia" has highlighted several important aspects of human spiritual development from an Islamic perspective of belief, kindness, sincerity, low self-esteem, qana'ah (grateful, patient). Based on the study of (36) on the development of human capital according to Imam AlGhazali found that spiritual development is divided into three dimensions which is oral communication, behavior and personality. According to Iman reference (37), the elements of spirituality such as trust, kindness, patience, low self-esteem and social contribute to the change of individual behavior. Reference (38) argues that the element of human spirit consists of elements of belief in god, kindness, patience, feel inferior in every treatment. The spiritual element of (38) is in line with the spiritual elements expressed by (39) and (40) which are trustworthy, patience, ihsan, humble and social. Reference (41) considers spirituality with the purification of the heart, as it requires setting up for all parts of the human body. He stressed that to purify the heart it must begin with the belief of Islam (Faith).

In spiritual development, an individual needs to have a strong belief in the greatness of God and to develop divine qualities such as taqwa (piety), tawakkul (belief in Allah), qana'ah, patience, sincerity and trust in the hereafter. A research done by (42) using in-depth interviews with successful entrepreneurs in the Small Medium Enterprise (SME) through case studies on entrepreneurial readiness shows that spirituality influences individuals in entrepreneurship selection as the career and spiritual elements required in the individuals itself who want to become entrepreneurs are honest, grateful, responsible, obedient to God, 9/10 sustenance in business, redha (acceptance) and strive for success

This spiritual element is essential to achieving excellence in the lives of students or individuals. This is because these spiritual elements can help the students or individuals to face the challenges and obstacles that come before any excellence can be achieved, especially in purifying the wishes of the MOHE in producing the holistic and entrepreneurial graduates.

\subsection{Spirituality as Antecedent of Students Entrepre- neurial Desires}

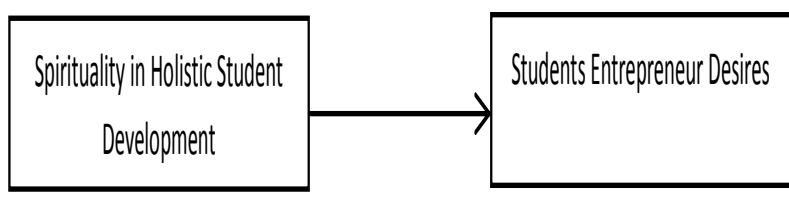

Fig. 1: Research conceptual model

The significance role of spirituality as a form of desire is fully captured and stressed in Islam (43). People are induced by spirituality to achieve pre-determined objectives. Figure 1 shows the conceptual model for this research. To obtain the elements of spiritual in holistic student development toward enhancing student's entrepreneur desire, researchers use meta-analysis base on the literature review as the first step in identifying the spiritual elements. Reference (44) averred that desires from Islamic perspective are by far more comprehensive than the approach of Western management theorists such as Maslow, McLealand and Freud because it has spiritual and material perspectives. Spiritual incentives may be the best alternative to material incentives (45). The dimensions of spirituality in holistic student development that form the basis of entrepreneurial desires had been identified from the literature above.

\section{Methodology}

\subsection{Research Design}

The data analysed for this study came from an extensive exploratory research initiative, including both interviews and document analysis. The aim of this research was to gain a clearer understanding of spirituality elements that it relates to student's entrepreneur desires by more fully understanding what inspired them. The interview conducted among eight lecturers of Malaysia Technical University Network (MTUN) whose experts in holistic student development and entrepreneurship. The criteria of experts in holistic student development and successful entrepreneurs from the perspective of informant are based on the experience not less than 10 years in student's development and teaching entrepreneurship co-curriculum at the university. Data were collected through in-depth interview based on specific protocol regarding the personal and experience in holistic student development, challenges and problems as well as the practice or approach that increasing student's entrepreneur desire. The process of data collection and analysis through in-depth interview conducted involving seven steps as mentioned by reference (46) including thematising (required thematic scope), designing (questionnaires in the interview protocol and remarks) interviewing (the process of interview), transcribing (transcribing to verbatim text) analysing (reading the transcribe and identifying the theme), verifying (concurring data credibility) and reporting (writing reports).

\section{Results and Findings}

\subsection{Informant Profile}

Table 1 below shows the details of the participant.

Table 1: Participant demographic details

\begin{tabular}{|c|c|c|c|c|c|c|c|c|}
\hline Profile & S1 & $\mathrm{S} 2$ & S3 & $\mathrm{S} 4$ & S5 & S6 & S7 & S8 \\
\hline \multicolumn{9}{|l|}{ Sex } \\
\hline Male & $\mathrm{x}$ & $\mathrm{x}$ & & $\mathrm{x}$ & & $\mathrm{x}$ & $\mathrm{x}$ & $\mathrm{x}$ \\
\hline Female & & & $\mathrm{x}$ & & $\mathrm{x}$ & & & \\
\hline \multicolumn{9}{|l|}{ Age } \\
\hline $35-44$ years & & & $\mathrm{x}$ & & & & & \\
\hline $45-54$ years & & & & $\mathrm{x}$ & $\mathrm{x}$ & & & \\
\hline 55-64 years & $\mathrm{X}$ & $\mathrm{x}$ & & & & $\mathrm{x}$ & $\mathrm{X}$ & $\mathrm{x}$ \\
\hline \multicolumn{9}{|l|}{ University } \\
\hline UTHM & $\mathrm{x}$ & $\mathrm{x}$ & & & & & & \\
\hline UMP & & & $\mathrm{x}$ & $\mathrm{x}$ & & & & \\
\hline UTeM & & & & & $\mathrm{x}$ & $\mathrm{x}$ & $\mathrm{x}$ & $\mathrm{x}$ \\
\hline \multicolumn{9}{|l|}{ UniMAP } \\
\hline \multicolumn{9}{|l|}{ Education } \\
\hline Master & & & $\mathrm{x}$ & & & & & \\
\hline Ph.D & $\mathrm{x}$ & $\mathrm{x}$ & & $\mathrm{x}$ & $\mathrm{x}$ & $\mathrm{x}$ & $\mathrm{x}$ & $\mathrm{x}$ \\
\hline \multicolumn{9}{|l|}{ Experts Category } \\
\hline $\begin{array}{l}\text { Students Devel- } \\
\text { opment }\end{array}$ & $\mathrm{x}$ & $\mathrm{x}$ & & $\mathrm{x}$ & $\mathrm{x}$ & $\mathrm{x}$ & $\mathrm{x}$ & $\mathrm{x}$ \\
\hline Entrepreneurship & & $\mathrm{x}$ & $\mathrm{x}$ & $\mathrm{x}$ & $\mathrm{x}$ & $\mathrm{x}$ & & $\mathrm{x}$ \\
\hline \multicolumn{9}{|l|}{ Experiences } \\
\hline 10-14 years & & & $\mathrm{x}$ & & & & & \\
\hline 15-19 years & & & & $\mathrm{x}$ & & & & $\mathrm{x}$ \\
\hline$>20$ years & $\mathrm{X}$ & $\mathrm{x}$ & & & $\mathrm{x}$ & $\mathrm{X}$ & $\mathrm{x}$ & \\
\hline
\end{tabular}

There are 8 participants in this research; 6 males and 2 females. They were classified into three age groups namely 35-44 years, 45-54 years and 55-64 years. Six of the participants (63\%) are from 55-64 years group, two participants (25\%) from $45-54$ years group and only one participant (13\%) from 34-44 years group. Majority of the participants have Ph.D education level and teaching experience in student development and entrepreneurship more than 20 years. 


\subsection{Spiritual Elements in Holistic Student Development toward Enhancing Student's Entrepreneur Desire}

\subsubsection{Document Analysis (Meta Data Analysis)}

From the foregoing, the elements of spirituality can be represented in Table 2 below based on the in-depth interview and the meta data analysis. The influence of these elements on entrepreneurship in relation to student's entrepreneur desire from the literature is to be explored in this study.

Meta-data analysis on Table 2 shows that patient (sabir) and trust was the most important element in spiritual holistic entrepreneur development. Spiritual element of humble and ihsan skor more than 50 percent agreement from previous researcher. For the conclusion, as far, researcher conclude that the most spiritual element required in holistic-entrepreneur student development are patient (sabir), trust, ihsan and humble.

\subsubsection{In-Depth Interview}

Based on the in-depth interview and the thematic analysis, it was found that there are three main themes toward enhancing student's entrepreneur desire; Purity of intention, Taqwa (piety) and Contentment (Qana'ah). Each theme is then divided into few sub themes which will give clearer pictures on the level of spiritual elements toward enhancing student's entrepreneur desire from the perspective of the informants. Fig. 2 shows the result of the research.

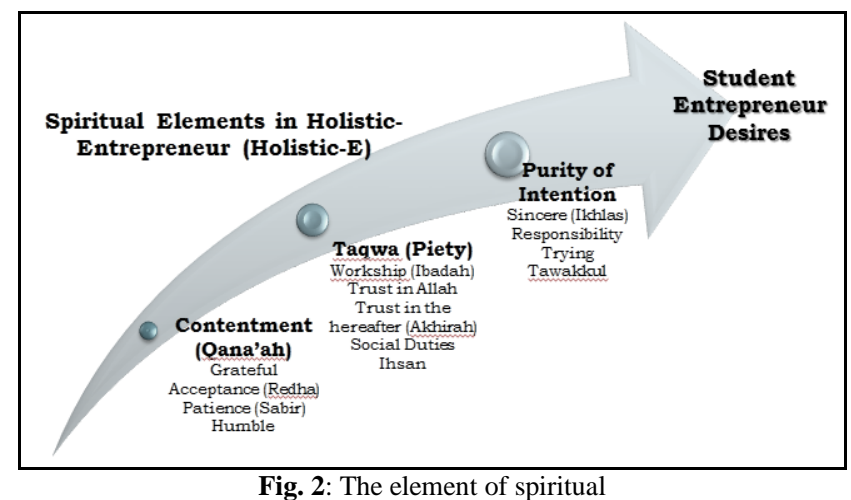

All title and author details must be in single-column format and must be centred.

Only the first word in a title must be capital and other word should be in small case. Author details must not show any professional title (e.g. Managing Director), any academic title (e.g. Dr.) or any membership of any professional organization (e.g. Senior Member IEEE).

To avoid confusion, the family name must be written as the last part of each author name (e.g. John A.K. Smith).

Each affiliation must include, at the very least, the name of the company and the name of the country where the author is based (e.g. Causal Productions Pty Ltd, Australia). Email address is compulsory for the corresponding author.

\section{Conclusion}

This research shows that the aspect of spirituality plays an important role towards enhancing students desire to become graduate entrepreneurs. This research had also found that the successful graduated entrepreneurs share the same characteristics of the spirituality even though they are in the different fields and categories. Spirituality which closely related to the internal elements based on faith towards Allah SWT creates positive attitudes and acts upon their actions in the practice of entrepreneurship. The themes and sub themes related to the characteristics of the spirituality practice influence the motivation of the entrepreneurs in building their confidence and self-perseverance, upholding the principle of morality and assisting responsible management which would bring success in their endeavours.

\section{Acknowledgement}

The authors would like to thank Ministry of Higher Education (MOHE) for funding this research. The support given by MOHE under Fundamental Research Grant Scheme (FRGS) Phase 1/2015 Vot No 1555 for providing the facilities to perform this research is highly appreciated

\section{References}

[1] Fristia VF, Navastara AM. Faktor Penyebab Belum Berkembangnya Industri Kecil Batik Desa Kenongo Kecamatan TulanganSidoarjo. Jurnal Teknik ITS. 2014 Sep 14;3(2):C190-5.

[2] Monitor GE. GEM 2016/2017 global report. Global Entrepreneurship Research Association, London Google Scholar. 2017.

[3] Amiruddin MH, Jafaar SN, Samad NA. Tahap Pengetahuan, Kemahiran dan Kebolehupayaan Pelatih Pendawaian Elektrik dalam Pembentukan Usahawan Teknikal Di Giatmara Negeri Johor. Sains Humanika. 2017 Mar 29;9(1-5).

[4] Che'Rus R, Azman MN. Pengaruh minat terhadap pembentukan pekerja berkemahiran di Malaysia: Kajian kes pelatih Institut Latihan Perindustrian Kuala Lumpur (ILPKL)(Influence of interest on the formation of skilled workers in Malaysia: The case of the Kuala Lumpur Industrial Training Institute). Geografia-Malaysian Journal of Society and Space. 2017 Sep 20;12(3).

[5] MoE M. Malaysia Education Blueprint 2015-2025 (Higher Education). Kuala Lumpur: Ministry of Education Malaysia. 2015.

[6] Chickering AW, Dalton JC, Stamm L. Encouraging authenticity and spirituality in higher education. John Wiley \& Sons; 2015 Jun 22.

[7] Rust AB, Gabriels CC. Spirituality in the workplace: Awareness of the human resources function. African Journal of Business Management. 2011 Feb 18;5(4):1353-64.

[8] Sheldrake P. Befriending our desires. Liturgical Press; 2016 Aug 18.

[9] Ratten V, Ramadani V, Dana LP, Gërguri-Rashiti S. Islamic Entrepreneurship and Management: Future Research Directions. InEntrepreneurship and Management in an Islamic Context 2017 (pp. 227-242). Springer, Cham.

[10] Agbim KC, Oriarewo GO. Spirituality as correlate of entrepreneurship development. Journal of research in national development. 2012;10(3):154-64.

[11] Mohamad B, Salleh MJ. Pembangunan modal insan sebagai satu pelaburan penting dalam konteks pembinaan negara.

[12] Abdullah MS. Faktor-faktor yang mempengaruhi pelajar-pelajar Diploma Kejuruteraan Politeknik dalam menceburi bidang keusahawanan (Doctoral dissertation, Universiti Tun Hussein Onn Malaysia).

[13] Othman N, Musa WA. Kesedaran Kendiri Terhadap Aktiviti Kokurikulum dan Keberkesanannya Kepada Remaja.

[14] Abdullah N, Yasin MH, Deli AA, Abdullah NA. Vocational Education as a Career Pathway for Students with Learning Disabilities: Issues and Obstacles in the Implementation. International Journal of Education and Social Science. 2015;2(3):98-104.

[15] Jali MF, Besar JA, Lyndon N, Ramachandran V. Persepsi politik belia India di Institusi Pengajian Tinggi Awam (IPTA) Malaysia (Political perception of Indian youths in Malaysia's public higher learning institutions). Geografia-Malaysian Journal of Society and Space. 2017 Sep 20;8(8).

[16] Mamat I, Nawang WM, Ramli NN. Nilai, Sikap dan Amalan Pegawai Kanan Institut Pengajian Tinggi Terhadap Program Pembangunan Usahawan Siswa (THE VALUE, ATTITUDE AND PRACTICE OF INSTITUTE OF HIGHER LEARNING'S SENIOR OFFICIALS TOWARDS GRADUATE ENTREPRENEUR DEVELOPMENT PROGRAMME). Jurnal Kemanusiaan. 2009;7(2).

[17] Hanapi Z, Nordin MS, Rus RC. Unemployment Problem among Graduates of Technical Field: Competencies of the Graduates and Quality of the Education. Sains Humanika. 2014 Sep 9;2(2).

[18] Stoppa TM. "Becoming More a Part of Who I Am:" Experiences of Spiritual Identity Formation Among Emerging Adults at Secular Universities. Religion \& Education. 2017 May 4;44(2):154-79. 
[19] Shahidah N. Pengaruh motivasi dalam proses pembangunan diri remaja menurut persepktif Islam: Kajian di Pusat Motivasi Aliran Pelajar, Kuala Lumpur (Doctoral dissertation, University of Malaya).

[20] Mustaqim M. Keluarga sakinah persepsi anak asuh (studi di resosialisasi Sunan Kuning Semarang) (Doctoral dissertation, UIN Walisongo).

[21] Fornaciari CJ, Dean KL. Diapers to car keys: The state of spirituality, religion and work research. Journal of management, spirituality \& religion. 2004 Jan 1;1(1):7-33.

[22] Kale SH, Shrivastava S. The enneagram system for enhancing workplace spirituality. Journal of Management Development. 2003 May 1;22(4):308-28.

[23] Jackson JJ, Konz GN. Spirituality and entrepreneurs. Journal of management, spirituality \& religion. 2006 Jan 1;3(3):242-57.

[24] Fry LW. Toward a theory of spiritual leadership. The leadership quarterly. 2003 Dec 1;14(6):693-727.

[25] Saroglou V, Muñoz-García A. Individual differences in religion and spirituality: An issue of personality traits and/or values. Journal for the Scientific Study of Religion. 2008 Mar;47(1):83-101.

[26] Nasr SH. Islamic Spirituality: Foundations. Routledge; 2013 Nov 5.

[27] Nasr SH. Traditional Islam in the modern world. Taylor \& Francis 1987.

[28] Rulindo R, Hidayat SE, Mardhatillah A. The importance of Spirituality for successful Entrepreneurs. Issues in Islamic Management. 2011:366-72.

[29] Al-Qaradawi Y. The Lawful and the Prohibited in Islam: ال حلال الإ سدلام ف ي وال حراد. The Other Press; 2013 Oct 11.

[30] Kamil M, Ali Hussain AK, \& Sulaiman MB. The components of spirituality in the business organizational context: The case of Malaysia. Asian Journal of Business and Management Sciences, 1(2), 166-180.

[31] Mubarak MZ, Rahman AA, Yaacob MR. Spirituality in Islamic Entrepreneurship: Motivation and Achievements Of Successful Entrepreneurs In Kelantan. Journal of Techno Social. 2014 Aug 24;6(2):27-36

[32] Mohsen, NRM. (2007). Leadership from the Qur'an, operationalization of concepts and empirical analysis: Relationship between Taqwa, trust, and business leadership effectiveness (Doctoral dissertation, Universiti Sains Malaysia, Malaysia).

[33] Zulkarnain K., Isa MA, (2011). Spirituality in Entrepreneurship from Islamic Perspective. Selangor: IIUM Press. 191-230.

[34] Azmi, IAG, Yaacob, Y. (2012). Entrepreneur's Personality from Islamic Perspective; A Study of Successful Muslim Entrepreneurs in Malaysia. International Conference on Economic Business Research. Phnom Penh. December 2012.

[35] Din H. Islam: Rujukan efektif akhlak mulia. PTS Litera Utama; 2007.

[36] Abdul Latif, A, Abdul Ghafar, MN, Libunao, WH, Mohd. Amin, N, \& Peter, CJ. (2013), Enhancing students akhlaq behaviour through holistic assessment. Proceeding of the International Conference on Social Science Research, ICSSR 2013. 502-518.

[37] Al-Ghazali I. (2006), Ihya Ulum Al-Din. Trans. By Ismail Takub. Vol. 3. Kuala Lumpur: Victory Ajensi.

[38] Uthaimun S. (1996), Makarimul Akhlaq. Trans. By Khalid Abu Shalih. Riyadh. Bandung: Darul Fajr.

[39] Al-Tusi, al-Din N. (1964), The Nasirean Ethics. Trans. By Wickens GM. London: George Allen \& Unwin Ltd.

[40] Miskawayh I, Muhammad A. (1961). Tahdhib al-Akhlaq. Beirut: Dar Maktabat al Hayat

[41] Ubale AZ, Abdullah AH (2015), The Effects Of Spirituality In Shaping The Human Behaviour (An Islamic Perspective), International Journal of Academic Research in Business and Social Sciences, 5 (9), 1-13.

[42] Hashim N, Othman N, \& Buang N (2009), Konsep Kesediaan Keusahawanan Berdasarkan Kajian Kes Usahawan Industri Kecil danSederhana (IKS) di Malaysia (ENTREPRENUERSHIP READINESS CONCEPT BASED ON CASE STUDY OF SMALL MEDIUM INDUSTRY (SMI) ENTREPRENEURS IN MALAYSIA). Jurnal Pendidikan Malaysia, 187 - 203

[43] Mohammed Adamu I, Kedah Z, Osman-Gani AM (2011), Spirituality in entrepreneurship from Islamic perspectives: a conceptual analysis on the effects on entrepreneurial motivation and social responsibility. 10th International Conference of the Academy of HRD (Asia Chapter), 3-6 December 2011 December, InterContinenta Hotel. (Unpublished)

[44] Chapra MU. The future of economics: An Islamic perspective. $\mathrm{Ku}$ be Publishing Ltd; 2016 Jul 4.
[45] Amin MR (2011), Motivating People in Organistaions: The Islamic way. In Ahmed K, Islam R, \& Ismail Y, (Eds.), Issues in Islamic Management (pp. 243-351) IIUP press.

[46] Kvale S. Doing interviews. Sage; 2008 Mar 5. 
Table 2: Meta Data analysis for spiritual elements in Holistic-Entrepreneur

\begin{tabular}{|c|c|c|c|c|c|c|c|c|c|c|}
\hline $\begin{array}{l}\text { Elements/ } \\
\text { References }\end{array}$ & $\begin{array}{l}\text { Haron } \\
\text { Din } \\
(2007)\end{array}$ & $\begin{array}{l}\text { Mohsen } \\
(2007), \\
\text { Kamil, } \\
(2011)\end{array}$ & $\begin{array}{c}\text { Zulkarnain } \\
\text { \& Isa, } \\
\text { (2011) }\end{array}$ & $\begin{array}{c}\text { Imam Al- } \\
\text { Ghazali } \\
(2006)\end{array}$ & $\begin{array}{c}\text { Syeikh } \\
\text { Uthaimin } \\
(1996)\end{array}$ & $\begin{array}{c}\text { Al-Tusi } \\
(1964)\end{array}$ & $\begin{array}{c}\text { Ibn } \\
\text { Masykawaih } \\
\text { (1961) }\end{array}$ & $\begin{array}{l}\text { Khaliq } \\
\text { (2011) }\end{array}$ & $\begin{array}{c}\text { Hashim, } \\
\text { Othman } \\
\text { \& Buang } \\
(2009) \\
\end{array}$ & $\begin{array}{l}\text { Percent- } \\
\text { age }\end{array}$ \\
\hline $\begin{array}{c}\text { Tawakkul (trust } \\
\text { in Allah/God) }\end{array}$ & $\sqrt{ }$ & $\mathrm{x}$ & $\sqrt{ }$ & $\mathrm{x}$ & $\mathrm{x}$ & $\mathrm{x}$ & $\mathrm{x}$ & $\mathrm{x}$ & $\mathrm{x}$ & 22 \\
\hline Patience (sabir) & $\sqrt{ }$ & $\sqrt{ }$ & $\sqrt{ }$ & $\sqrt{ }$ & $\sqrt{ }$ & $\sqrt{ }$ & $\sqrt{ }$ & $\sqrt{ }$ & $\sqrt{ }$ & 100 \\
\hline Trust & $\sqrt{ }$ & $\sqrt{ }$ & $\sqrt{ }$ & $\sqrt{ }$ & $\sqrt{ }$ & $\sqrt{ }$ & $\sqrt{ }$ & $\sqrt{ }$ & $\sqrt{ }$ & 100 \\
\hline Sincere/Ikhlas & $\sqrt{ }$ & $\mathrm{x}$ & $\sqrt{ }$ & $\mathrm{x}$ & $\mathrm{x}$ & $\mathrm{x}$ & $\mathrm{x}$ & $\sqrt{ }$ & $\sqrt{ }$ & 44 \\
\hline Taubat & $\mathrm{x}$ & $\sqrt{ }$ & $\mathrm{x}$ & $\mathrm{x}$ & $\mathrm{x}$ & $\mathrm{x}$ & $\mathrm{x}$ & $\mathrm{x}$ & $\mathrm{x}$ & 11 \\
\hline Dhikr & $\mathrm{x}$ & $\mathrm{x}$ & $\sqrt{ }$ & $\mathrm{x}$ & $\mathrm{x}$ & $\mathrm{x}$ & $\mathrm{x}$ & $\mathrm{x}$ & $\mathrm{x}$ & 11 \\
\hline $\begin{array}{c}\text { Trust in the } \\
\text { hereafter } \\
\text { (akhirah) }\end{array}$ & $\sqrt{ }$ & $\mathrm{x}$ & $\sqrt{ }$ & $\mathrm{x}$ & $\mathrm{x}$ & $\mathrm{x}$ & $\mathrm{x}$ & $\sqrt{ }$ & $\sqrt{ }$ & 44 \\
\hline Worship & $\sqrt{ }$ & $\sqrt{ }$ & $\mathrm{x}$ & $\mathrm{x}$ & $\mathrm{x}$ & $\mathrm{x}$ & $\mathrm{x}$ & $\mathrm{x}$ & $\sqrt{ }$ & 33 \\
\hline Taqwa (piety) & $\sqrt{ }$ & $\mathrm{x}$ & $\mathrm{x}$ & $\mathrm{x}$ & $\mathrm{x}$ & $\mathrm{x}$ & $\mathrm{x}$ & $\sqrt{ }$ & $\sqrt{ }$ & 33 \\
\hline Ihsan & $\sqrt{ }$ & $\mathrm{x}$ & $\mathrm{x}$ & $\sqrt{ }$ & $\sqrt{ }$ & $\sqrt{ }$ & $\sqrt{ }$ & $\mathrm{x}$ & $\mathrm{x}$ & 56 \\
\hline Social & $\mathrm{x}$ & $\mathrm{x}$ & $\mathrm{x}$ & $\sqrt{ }$ & $\mathrm{x}$ & $\sqrt{ }$ & $\sqrt{ }$ & $\mathrm{x}$ & $\mathrm{x}$ & 33 \\
\hline Humble & $\sqrt{ }$ & $\mathrm{x}$ & $\mathrm{x}$ & $\sqrt{ }$ & $\sqrt{ }$ & $\sqrt{ }$ & $\sqrt{ }$ & $\mathrm{x}$ & $\mathrm{x}$ & 56 \\
\hline $\begin{array}{l}\text { Redha (ac- } \\
\text { ceptence) }\end{array}$ & $\sqrt{ }$ & $\mathrm{x}$ & $\mathrm{x}$ & $\mathrm{x}$ & $\mathrm{x}$ & $\mathrm{x}$ & $\mathrm{x}$ & $\mathrm{x}$ & $\sqrt{ }$ & 22 \\
\hline Responsible & $\mathrm{x}$ & $\mathrm{x}$ & $\mathrm{x}$ & $\mathrm{x}$ & $\mathrm{x}$ & $\mathrm{x}$ & $\mathrm{x}$ & $\mathrm{x}$ & $\sqrt{ }$ & 11 \\
\hline Trying & $\mathrm{x}$ & $\mathrm{x}$ & $\mathrm{x}$ & $\mathrm{x}$ & $\mathrm{x}$ & $\mathrm{x}$ & $\mathrm{x}$ & $\mathrm{x}$ & $\sqrt{ }$ & 11 \\
\hline $\begin{array}{l}\text { Contentment/ } \\
\text { Qana'ah }\end{array}$ & $\sqrt{ }$ & $\mathrm{x}$ & $\mathrm{x}$ & $\mathrm{x}$ & $\mathrm{x}$ & $\mathrm{x}$ & $\mathrm{x}$ & $\mathrm{x}$ & $\sqrt{ }$ & 22 \\
\hline
\end{tabular}

